\title{
Health Tourism in Turkey: Opportunities and Threats
}

\author{
Dr. Esma Gültüvin Gür Omay \\ Prof. Dr. Emrah Cengiz
}

\section{Doi:10.5901/mjss.2013.v4n10p424}

\section{Abstract}

Health Tourism is becoming an upward trend in our globalised world. Health tourism can be simply defined as travelling of the individuals to other countries to seek medical care. Increased health care expenses in the West and the globalisation have led individuals to seek health care in other countries that provide affordable health care. On the other hand, wellness and antiaging practices are also gaining ground in today's modern world. The urge to look good on individuals as a result of the existing trends in today has also led the individual to seek advice in wellness and anti-aging. The changes in life styles and health marketing policies on wellness and anti-aging practices, lack of adequate insurances, high costs and travel means have increased the interest on health tourism. Turkey is a good destination for health tourism. Because of the high quality of service provided at an affordable cost. Also, there are no long waiting lines for foreign patients; the visa procedures are easy for most of the nations. The purpose of this paper is to outline the opportunities and threats of health tourism in Turkey.

Keywords: health tourism, medical tourism,opportunities, threats, Turkey.

\section{Introduction}

Since the 1970s globalisation has affected political, economic and socio-cultural features all around the world. One of the important issues about that transformation is the development of health tourism. Although the concept of health tourism is not the result of globalisation, it has transformed into a massive export of services all around the globe. Some countries focus on health tourism to gain a competitive advantage among the other countries. Turkey has many advantages to become one of the most high ranked health tourism countries. The aim of this paper is to argue briefly Turkey's health tourism related opportunities and threats.

\section{Health Tourism: General Concepts}

Health Tourism is becoming an upward trend for the last decades. Many countries focus on the health tourism issue for the last decades as it has become a remarkable service for export. Although the popularity of health tourism has been increasing as a result of globalization for the last decades, it has been an issue of at least two millenniums. There are many records that ancient Greeks and Romans travelled to long distances in order to seek healing and having bath in thermal waters. Its popularity is related with the increasing number of both health tourists and activities (Reisman, 2010: 1). Some records show that health tourism can be dated back to $4.000 \mathrm{BC}$ when Sumerians used hot waters for the purpose of medical care (Ministry of Health, 2012: 19).

But for many popular concepts, there is much of an ambiguity on the definition and meaning of health tourism. Health tourism ,what it is and what covers it, is a long disputed subject. The notion of work when taken historically brought different types of perception and understanding.

In order to understand the health tourism as a concept, it should be focused on the two concepts that health tourism is derived from: Health and tourism. According to Merriam Webster dictionary health is defined such as follows:

\footnotetext{
" 1 a : the condition of being sound in body, mind, or spirit; especially : freedom from physical disease or pain

$b$ : the general condition of the body ...

2 a : flourishing condition ...

$b$ : general condition or state ...

3 : a toast to someone's health or prosperity" (www.m-w.com)
} 
World Health Organisation (WHO) defines the concept of health such as follows: "Health is a state of complete physical, mental and social well-being and not merely the absence of disease or infirmity" (www.who.int). As it might be seen from the definitions given above, there is a common consensus on the definition and meaning of health.

Yet according to Merriam Webster dictionary tourism is defined such as follows:

" 1 : the practice of traveling for recreation

$2:$ the guidance or management of tourists

$3 \mathrm{a}$ : the promotion or encouragement of touring

$b$ : the accommodation of tourists" (www.m-w.com)

It is clear that the first meaning of tourism is already related with health as the stress is on "recreation". Therefore, the interconnectivity of those two words is obvious and the meaning of the health tourism becomes evident: "The practice of traveling for health". Nevertheless, it is not so clear in the literature of health tourism since there is much of argument on the concept.

As being a popular concept, there are few consensus on the concept of Health Tourism. One of the most important issues on the ambiguity of the concept is related with its definitions. Indeed there are some other concepts similar to Health Tourism such as Medical Tourism and Wellness Tourism. Some authors prefer to use the concepts of health tourism and medical tourism without taking any measures on their differences while some others prefer to make a distinction between those two concepts (Smith and Puczko, 2009: 101). For instance,

"The terms "medical tourism" and "health tourism" refer to treatments or surgery that have been planned in advance to take place outside a patient's usual place of residence" (Terry, 2007: 416).

"... a distinction must be made between health tourism and medical tourism, whereby medical tourism is the correct term to use in cases in which medical interventions are required" (Yu and Ko, 2012: 81).

As seen from the quotations given above, the need for giving a clearer definition is obvious. According to some authors the term medical tourism is a subset of health tourism (Pocock and Phua, 2011: 2) according to some others medical tourism is a new niche in the health tourism industry (Connell, 2006: 1). Indeed, according to Connell, historically health tourism is the oldest kind of health related tourism since "tourism has always been associated with improved health and well-being" (2006: 1). A comprehensive analysis on the differences between health tourism and medical tourism is shown in Table 1:

Table 1. Selected definitions for health and medical tourism.

\begin{tabular}{|l|l|l|}
\hline \multicolumn{1}{c}{ Health tourism } & \multicolumn{1}{c}{ Medical tourism } \\
\hline $\begin{array}{l}\text { Supply } \\
\text { perspective }\end{array}$ & $\begin{array}{l}\text { Provision of healthcare services to } \\
\text { nonordinary residents }\end{array}$ & $\begin{array}{l}\text { Exotic travel (especially to a developing region) with a } \\
\text { brief opportunity to practice medicine }\end{array}$ \\
$\begin{array}{l}\text { Business of providing medical care for } \\
\text { foreign patients }\end{array}$ & $\begin{array}{l}\text { Travel to poor countries by clinical professionals from } \\
\text { rich countries for short-term work }\end{array}$ \\
$\begin{array}{l}\text { Demand } \\
\text { perspective }\end{array}$ & $\begin{array}{l}\text { Travel to avail of medical care } \\
\text { Travel to avail of medical services }\end{array}$ & Influx of foreigners for medical care \\
\hline
\end{tabular}

Source: Carrera and Bridges, 2006: 448.

As seen in Table 1, the classification of two concepts are not strictly differ them at all. But according to another dichotomy made by Cohen, shows a strict difference between the concepts of health tourism and medical tourism. Cohen prefers to define at first the concept of medical tourist in order to define medical tourism. According to Cohen there are five types of tourist which are classified such as follows (2008: 25-26).

1) Mere tourist: A mere tourist is someone who is only on vacation abroad without seeking any medical treatment.

2) Medicated tourist: A medicated is someone who incidentally needs medical treatment during the vacation abroad. 
3) Medical tourist proper: A medical tourist proper is someone who intends to benefit from both medical treatment and touristic activities at the same time abroad.

4) Vacationing patient: A vacationing patient is someone who intends to benefit also from touristic activities during the medical treatment abroad.

5) Mere patient: A mere patient is someone who is abroad only for seeking medical treatment.

That classification seems to serve not to clarify the difference between health tourism and medical tourism but to make it clear that the medical tourism cannot be defined only by intended purpose medical tourists as the mediated tourists do not have the purpose of medical treatment. Another important point of Cohen's classification is related with the scope of the health tourism yet it highlights the different levels of health tourism.

According to some authors health tourism is a composition of three main categories which are "Services to Improve Health (spa, herbal therapy, massage, etc.), Services for treatment - Medical Tourism (cosmetic surgery, heart surgery, eye surgery, cancer therapy, etc), [and] Rehabilitation Services (dialysis, addiction programs, elder care program)"(Ministry of Health, 2012: 18):

According to the Turkish Ministry of Health, "health tourism" might be considered as a combination of three subjects which are,

1. Medical tourism,

2. Thermal tourism,

3. Elderly and Disabled Tourism (Ministry of Health, 2012: 18).

It is clear that Turkish Ministry of Health considers medical tourism as a subset of health tourism which is appropriate to the commonsense in the related literature.

\section{Benefits of Health Tourism}

The benefits of health tourism might be argued under two main subjects. The first one is the benefits for the health service exporter countries and the other one is the benefits for the health tourists.

\subsection{Benefits of Health Tourism for Health Service Exporter Countries}

It might be surprising to assume the health service as an exporting goods but it is. Since the very nature of the medical care and health service, the buyer and the seller should be in the same room. Yet, it is true that with the development of technology it has become possible to manage a surgery by using robotic instruments controlled via telecommunication technologies, the most of the health related services are in need to be carried with direct connection (Reisman, 2010: 1920; Cohen, 2008: 34). Needless to say that in the health tourism the buyer of the service has to pass the border physically or virtually.

By an economic view, health tourism is a kind of export-import relation between countries. Because, in this process some countries export the services of other countries while some other countries import those services. In this case, the health care is a kind of service which is demand by the clients who are foreigners. Indeed:

"The American patient is importing a service when he travels to Thailand to spend American dollars in a local clinic. The British hospital is exporting a service when it supplies major surgery to a Lebanese who has bought British first" (Reisman, 2010: 99).

It is estimated that the total volume of health tourism export revenues is about 100 billion USD (Özer and Sonğur, 2012: 70) and it is likely to increase in the next years. Therefore, health tourism has been becoming a remarkable industry for the countries. On the other hand, the industry promises gains more than its own revenues.

The benefits of health tourism for health service exporter countries might be considered in many different classifications, such as direct benefits and indirect benefits, tangible benefits and intangible benefits, visible benefits and invisible benefits, etc.

It should be noted that health tourism has more positive effects than it is expected. For instance, as it is a service based industry, health tourism helps to protect reserves. And also it helps to improve the skills of human resource and creates employment not only for skilled employees but also for unskilled and semi-skilled employees. Its multiplier effect for the economy is really very high as it needs complicated organizations, such as the need for building of new medical buildings, employing gardeners, cooks, etc. Moreover, investments for health tourism improve the quality of lives of the exporter countries citizens. On the other hand, health tourists do not prefer to travel alone (Reisman, 2010: 102-103). 


\title{
3.2 Benefits of Health Tourism for Health Tourists
}

One of the important points on the health tourism issue is that the impetus on the increasing numbers of health tourist is mostly economic. As noted by Cohen, "Over the last decades, medical services in a large number of highly developed countries have become increasingly more expensive and in some cases no longer affordable or accessible to large segments of the Population" (2008: 25). Therefore, the most obvious benefit of health tourism for health tourist is that it is cheaper comparing with his/her own country's health care system. For instance,

\begin{abstract}
"For complex surgery the [cost] differences are considerable. In 2003 a small child in the United States with a hole in her heart was faced with a bill of around $\$ 70,000$ there, but the operation was carried out in Bangalore, India at a cost of $\$ 4400$... Open heart surgery may cost about $\$ 70,000$ in Britain and up to $\$ 150,000$ in the United States but in India's best hospitals it costs between $\$ 3000$ and $\$ 10,000$ depending on how complicated it is. Dental, eye and cosmetic surgery costs about a quarter of that in western countries" (Connell, 2006: 1097).
\end{abstract}

Although the economic advantage is obvious there are some other reasons to prefer health tourism. Some patients may prefer to be treated in the countries in which health care is carried on with high technology and better standards. In some countries the waiting lists are so long that some patients may prefer to attend to health tourism in order to shorten the waiting period. Some patients may have difficulties with their health insurance since those insurances may not cover some treatments (such as aesthetic surgeries), so the patients are to pay all the cost. On the other hand, some patients prefer to go abroad for medical treatment as those treatments are restricted in their own countries (Ministry of Health, 2012: 13; Erdoğan and Yilmaz, 2012: 1045-1046).

\section{Health Tourism in Turkey}

Starting from 1980s, Turkey has become a popular and attractive country for the tourists coming from all around the world. According to the recent statistics of United Nations World Tourism Organization (UNWTO), Turkey is in the $6^{\text {th }}$ rank in the world, with arrivals of 35.7 million tourists in the year of 2012 (UNWTO, 2013: 6). The reasons of that remarkable result are the rich heritage of history and culture, but also the favourable climate.

In the recent years Turkey has been becoming a popular country for health tourism. Not only the advanced health facilities but also the touristic advantages are the reasons for that popularity. As a result, Turkey offers not only medical tourism but also health tourism as a whole for the foreign patients. In other words, as a state policy, Turkey seeks for a competitive advantage on health tourism with the power of her tourism experience.

As aforementioned above, the context of health tourism is implicit and highly arguable. Therefore, countries prefer to consider their policies related with health tourism with their own considerations according to their legal and sociocultural structures as well as the degree of development in medical science and technology.

As noted above, the Turkish Ministry of Health, has preferred to define "health tourism" with the composition of these three subjects which are,

1. Medical tourism,

2. Thermal tourism,

3. Elderly and Disabled Tourism (Ministry of Health, 2012: 18).

Therefore, the state policies related with health tourism of Turkey might be considered with the view of that definition. The health tourism has become a state policy, and as a result of the fact that health tourism has begun to cover by legal regulations starting from 2011. Also Ministry of Health has become the responsible on the health tourism matters. Therefore, the Ministry reorganized and a central unit (Department of Health Tourism) founded in order to regulate the health tourism on national basis. On the other hand, Turkey has undergone a serious reorganization of health care system since 2002. The purpose of the reorganization is to make the health care system more efficient, more effective, and available with modernization and increasing the quality standards (Özer and Sonğur, 2012: 76).

Recent studies show that the reorganization of health care system has begun to yield positive outcomes since "foreign patients from all over the world come to Turkey to health institutions for plastic surgery, eye operations, hair [trans]plantation, fertility, open heart operations, dermatology, cancer treatments, brain surgery, [orthopaedics], dental operations, etc. for lower prices with high-tech standards" (BAKA, 2011: 16).

Having lower prices with high-tech standards seems to gain a real competitive advantage for Turkish health tourism industry. In Table 2 some prices of surgeries are given in order to make more evident comparison. 
Table 2. Price Statistics of Selected Surgeries in Some Countries (USD 1.000)*

\begin{tabular}{|l|c|c|c|c|c|c|c|c|c|c|c|}
\hline SURGERY & US & TR. & IE. & TH. & DE. & TW. & SG. & IN. & IL. & ENG. & CH. \\
\hline Heart Bypass (CABG) & 130 & $11-15$ & $27-28$ & 11 & 17 & 19 & $30-33$ & 9 & 30 & 28 & 45 \\
\hline Heart Valve Replacement & 58 & 17 & N/A & 10 & N/A & 28 & 13 & 12 & 25 & 25 & 48 \\
\hline Hip Replacement & 45 & 11 & $20-21$ & $11-14$ & 12 & 8 & 11 & 7 & 17 & 16 & 20 \\
\hline Knee Replacement & 40 & 11 & $20-21$ & 11 & 12 & 8 & 9 & 8 & 13 & 21 & 20 \\
\hline Spinal Fusion & 62 & 7 & $25-26$ & 7 & $14-15$ & 6 & 9 & 12 & 18 & 32 & 31 \\
\hline Bone Marrow Transplant. & 300 & $40-70$ & 250 & $50-60$ & 250 & $50-60$ & 250 & 40 & 90 & 250 & 200 \\
\hline Gamma Knife & 40 & 9 & --- & --- & $17-20$ & --- & --- & --- & --- & $22-25$ & \\
\hline
\end{tabular}

* The prices are brung up.

US: United States, TR: Turkey, IE: Ireland, TH: Thailand, DE: Germany, TW: Taiwan, SG: Singapore, IN: India, IL: Israel, ENG: England, $\mathrm{CH}$ : Switzerland.

Source: DEIK Price Statistics (http://www.healthinturkey.org/en-EN/Price.aspx) (accessed in 06.07.2013).

Moreover, as increasing the quality standards "today, Turkey is shown among the key medical tourism destinations by the international authorities particularly in following treatment types: organ and bone marrow transplantation, cardiology and cardiovascular surgery, oncology, gamma knife, in vitro fertilization, orthopedics and traumatology, spine surgery, neurosurgery, reproductive health and pre-implantation genetic diagnosis, plastic surgery, dental services, ophthalmology" (Erdoğan and Yilmaz, 2012: 1052).

\section{Health Tourism in Turkey: Opportunities and Threats}

As a popular touristic destination, Turkey has been ranked in the top ten countries in the previous years. The popularity of Turkey as a touristic destination is a result of not only her historical and cultural richness but also her climate and natural resources. Moreover, Turkey has invested and focused on tourism industry for the last decades.

Tourism has been known as a popular industry in all around the globe and countries try to make their best in order to gain competitive advantage in this trade. According to the 2013 year report of UNWTO which announced the results for the year 2012, tourism is actually a promising industry and global trade by all means. For instance, it was the source of $9 \%$ of total global GDP with its direct, indirect, and induced impact; it created each 1 of 11 jobs yet with its direct, indirect, and induced impact; its total trade volume for export was about 1.3 billion USD which was the $6 \%$ of total volume of exports (UNWTO, 2013: 2). As a result of the fact, the great interest of countries on tourism industry should not be considered as fading.

As a great player Turkey shows much of interest on tourism and she gained approximately 23 billion USD in 2010, 25 billion USD in 2011, and 26 billion USD in 2012 (UNWTO, 2013: 8). But the point is that, Turkey is not among the top ten countries which gain the highest income from tourism industry as it may be seen in Table 3 .

Table 3. International Tourist Arrivals and International Tourism Receipts of top ten countries in 2012.

\begin{tabular}{|l|c|c|l|c|c|}
\hline \multicolumn{3}{|c|}{ International Tourist Arrivals } & \multicolumn{3}{c|}{ International Tourism Receipts } \\
\hline \multicolumn{1}{|c|}{ Rank in 2012 } & \multicolumn{2}{c|}{ Million } & \multicolumn{2}{c|}{ USD Billion } \\
\hline 1 France & $\mathbf{2 0 1 1}$ & $\mathbf{2 0 1 2}$ & Rank in 2012 & $\mathbf{2 0 1 1}$ & $\mathbf{2 0 1 2}$ \\
\hline 2 United States & 81.6 & 83.0 & 1 United States & 115.6 & 126.2 \\
\hline 3 China & 62.7 & 67.0 & 2 Spain & 59.9 & 55.9 \\
\hline 4 Spain & 57.6 & 57.7 & 3 France & 54.5 & 53.7 \\
\hline 5 Italy & 56.2 & 57.7 & 4 China & 48.5 & 50.0 \\
\hline 6 Turkey & 46.1 & 46.4 & 5 Macao (China) & 38.5 & 43.7 \\
\hline 7 Germany & 34.7 & 35.7 & 6 Italy & 43.0 & 41.2 \\
\hline 8 United Kingdom & 28.4 & 30.4 & 7 Germany & 38.9 & 38.1 \\
\hline 9 Russian Federation & 29.3 & 29.3 & 8 United Kingdom & 35.1 & 36.4 \\
\hline 10 Malaysia & 22.7 & 25.7 & 9 Hong Kong (China) & 27.7 & 32.1 \\
\hline
\end{tabular}

Source: Derived from UNWTO, 2013: 6. 
As seen in the Table 3, although Turkey is a popular destination for international tourist, there is a mismatch between the number of international tourist arrivals and international tourism receipt. Indeed, it has been a long disputed subject in Turkey whether Turkey has been following the true strategies and policies for tourism industry since she cannot be able to gain the income as it should be. For instance, as seen from Table 3, the United States managed to earn approximately 1.884 USD per tourist in 2012 while Spain managed to earn approximately 969 USD per tourist in 2012. Turkey managed to earn approximately only 728 USD per tourist in 2012 while the Germany managed to earn nearly $47 \%$ more than Turkey with a less number of tourists (approximately $17 \%$ ). Yet, it is quite clear that although Turkey is a popular destination for international tourists, she is not a popular destination for rich ones.

The strategies for gaining a competitive advantage might be considered as the reason of that problem because has much focused on offering world standard quality blended with rich cultural heritage and rich natural environment for an inexpensive, affordable price. Moreover, the all inclusive package tours have been promoted the with the selling idea and slogan "Leave your wallet at home!".

Focusing on health tourism may give a chance for Turkey to increase her trade volume and gaining from tourism industry since there is plenty of excess capacity to develop health tourism industry. Therefore, Turkish Ministry of Health has started to promote health tourism in order to develop and gain a competitive advantage in tourism industry. According to the Ministry Turkey's competitiveness elements in health tourism are such as follows: "World standard quality, Personal service, Short waiting time, Rich cultural heritage, and Cheap service" (Ministry of Health, 2012: 27). According to a report of Turkish Health Ministry the SWOT analysis of Health Tourism in Turkey is shown in Table 4.

Table 4. SWOT Analysis of Health Tourism in Turkey

\begin{tabular}{|l|l|}
\hline Strengths & Weaknesses \\
\hline - A leading country of health sector in the world, & $\begin{array}{l}\text { - Focusing too much on production and neglecting } \\
\text { the importance of marketing, }\end{array}$ \\
- Having lots of alternative touristic opportunities, & Very few organisations support health tourism, \\
- Well qualified service sector, & Weak cooperation between health tourism \\
- Astablishments, \\
experience on health tourism,
\end{tabular}

Source: Derived from Ministry of Health, 2012: 61-62. 
The results of the recent years have shown that health tourism has a promising future for Turkish tourism industry since there is rapid growing in the number of foreign patients received health treatment in Turkey as shown in Table 5:

Table 5. The Foreign Patients Receiving Health Service in Turkey

\begin{tabular}{|c|c|c|c|c|}
\hline Years & $\begin{array}{c}\text { Public Health } \\
\text { Establishments }\end{array}$ & $\begin{array}{c}\text { Private Health } \\
\text { Establishments }\end{array}$ & Total & $\begin{array}{c}\text { Change } \\
(\%)\end{array}$ \\
\hline 2008 & 17,817 & 56,276 & 74,093 & --- \\
\hline 2009 & 21,442 & 70,519 & 91,961 & 24 \\
\hline 2010 & 32,675 & 77,003 & 109,678 & 19 \\
\hline 2011 & 41,847 & 114,329 & 156,176 & 42 \\
\hline 2012 & $84,000^{\star}$ & $186,000^{\star}$ & $270,000^{\star}$ & 73 \\
\hline
\end{tabular}

*Estimated.

Source: Derived from Ministry of Health, 212: 33.

As indicated above the strategies are not adopted only for medical tourism but in a more common and wide sense. Yet, the Centre for Health Tourism of Turkish Ministry of Health has been organised under these sections: International coordination, health tourism, thermal tourism spa-wellness, and elderly-disabled tourism (Ministry of Health, 2012: 29). On the other hand, legal regulations, international co-operations, co-operations among the state bodies (such as Turkish Ministry of Foreign Affairs has been much busy for the abolition of visas with many countries and Turkish Ministry of Finance has begun to support health tourism by tax allowances), co-operations among public and private sector organizations (such as the support of Turkish Airlines for packet organizations with discounted prices) are quite remarkable efforts to support health tourism (Erdoğan and Yilmaz, 2012: 1055-1056). Another important point is that Turkey in the $3^{\text {rd }}$ rank for the "highest number of $\mathrm{JCl}$ accredited hospitals in the world" which is expected to yield positive results. Moreover, having close to 60 high qualified medical faculties training not only Turkish students but also foreign medical students, being in the cross-road between Europe and Asia, being the regional headquarters and manufacturing facilities of almost all major companies (such as Pfizer, GlaxoSmithKline, Johnson and Johnson, Sanofi-Aventis, Merck, Novartis, Roche, Astra Zeneca) and reliable supply of blood provided by Turkish Red Crescent (which is also accredited by $\mathrm{JCl}$ ) are among the advantages of Turkish health tourism industry (www.healthinturkey.org). Therefore, health tourism seems as a promising industry for Turkey.

\section{Conclusion}

Health tourism is an upward trend in the global tourism industry. Although health tourism is an old concept, it has gained popularity as a result of globalization. Therefore, health tourism as a concept has been much of interest in the academic literature. Nevertheless, there is much of ambiguity on the meaning and the context of the health tourism concept. But in a common sense, health tourism is related with going abroad to receive health care. In the developed countries as the health care costs are high, the patients of those countries have begun to prefer to receive health care and medical treatment in the countries offering at least the same quality and standard for the inexpensive prices. On the other hand, high prices are not the only reason of the issue; there are some other reasons such as long waiting lists, restrictions of some treatments. Some countries have begun to show much of interest on appealing those patients as tourists. Turkey is among of those countries. Turkey has just started to pay attention on the issue for the last years as a result of the mismatch between the number of international tourist arrivals and the total of revenue gained from them. Although Turkey is in the $6^{\text {th }}$ rank among the popular destinations, she cannot gain much of that .It seems that Turkey is willing to combine her tourism capacity with her health care service capacity to gain a competitive advantage on sharing a greater portion from that ever increasing niche market of tourism industry. Although Turkey has to overcome some threats, with her potential and willingness on making efforts, health tourism seems to be a promising industry of the near future.

\section{References}

BAKA (Western Mediterranean Development Agency) (2011), Health Report Tourism Sector Report, February.

Carrera, Percivil M. and Bridges, John F.B. (2006), "Globalization and Healthcare: Understanding Health and Medical Tourism", Expert Review of Pharmacoeconomics \& Outcomes Research, 6 (4). 
Cohen, Erik (2008), "Medical Tourism in Thailand", AU-GSB e-journal, 1 (1).

Connell, John (2006), "Medical Tourism: Sea, Sun, Sand and ... Surgery", Tourism Management, 27.

Erdoğan, Seyfettin and Yilmaz, Emine (2012), "Medical Tourism: An Assessment on Turkey", International Joint Conference of 10th International Conference on Knowledge, Economy and Management; 11th International Conference of the ASIA Chapter of the AHRD \& 2nd International Conference of the MENA Chapter of the AHRD Proceedings.

Health, http://www.merriam-webster.com/dictionary/health (Accessed 05.07.2013).

Ministry of Health, (2012), Evaluation Report on Medical Tourism in Turkey 2012, Prepared by: Mehmet Barca, Erdal Akdeve, iklim Gedik Balay, IIfan Şencan, and Dursun Aydın, Republic of Turkey Ministry of Health Directorate General of Health Services Department of Health Tourism, Opus Printing LLC.

Özer, Özlem and Sonğur, Cuma (2012), "Türkiye'nin Dünya Sağlık Turizmindeki Yeri ve Ekonomik Boyutu", Mehmet Akif Ersoy Üniversitesi Sosyal Bilimler Enstitüsü Dergisi, 4 (7).

Pocock, Nicola S. and Phua, Kai Hong (2011), "Medical Tourism and Policy Implications for Health Systems: A Conceptual Framework from a Comparative Study of Thailand, Singapore and Malaysia", Globalization and Health, 7(12).

"Price Statistics", DEIK (Foreign Economic Relations Board), (http://www.healthinturkey.org/en-EN/Price.aspx) (accessed in 06.07.2013).

Reisman, David (2010), Health Tourism: Social Welfare Through International Trade, Edward Elgar Publishing Limited, Cheltenham.

Smith, Melanie and Puczko, Laszlo (2009), Health and Wellness Tourism, Elsevier Ltd.

Terry, Nicholas P. (2007), "Under-Regulated Health Care Phenomena in a Flat World: Medical Tourism and Outsourcing", Western New England Law Review, 29.

Tourism, http://www.merriam-webster.com/dictionary/tourism (Accessed 05.06.2013).

UNWTO (United Nations World Tourism Organization) (2013), UNWTO Tourism Highlights, 2013 Edition.

Yu, Jin Yun and Ko, Tae Gyo (2012), "A Cross-Cultural Study of Perceptions of Medical Tourism among Chinese, Japanese and Korean Tourists in Korea", Tourism Management, 33.

"WHO Definition of Health", World Health Organization, http://www.who.int/about/definition/en/print.html, (Accessed 05.07.2013).

"Why Turkey?", DEIK (Foreign Economic Relations Board) (http://www.healthinturkey.org/en-EN/why-turkey/2.aspx) (accessed in 06.07.2013). 